http://dx.doi.org/10.18778/1509-877X.03.04

\title{
ROZWÓJ KONCEPCJI TREŚCI EKONOMICZNEJ (sUbSTANCE) W WielKiej BRyTANII
}

\begin{abstract}
Streszczenie. Jednym ze sposobów przeciwdziałania unikaniu opodatkowania jest poszukiwanie i badanie w działaniach podatników elementu treści ekonomicznej (ang. substance). Może to nastąpić $\mathrm{w}$ formie opartych na elementach substance doktryn orzeczniczych, a także w formie konkretnych zapisów ustawowych (np. skodyfikowanych klauzul ogólnych przeciwko unikaniu opodatkowania). W Wielkiej Brytanii doktryny orzecznicze oparte na koncepcji substance nie znalazły szerszego zastosowania. W szczególności na gruncie brytyjskim nie przyjęły się doktryny funkcjonujące np. w Stanach Zjednoczonych (economic substance, business purpose, substance over form). Natomiast doktryny wypracowane przez rodzime orzecznictwo (zasada Ramsay, New Approach) ostatecznie nie dały możliwości rozstrzygania na podstawie treści ekonomicznej, z pominięciem litery prawa. Element treści ekonomicznej został natomiast w sposób pośredni uwzględniony w brytyjskiej klauzuli ogólnej przeciwko nadużyciu prawa podatkowego.
\end{abstract}

Słowa kluczowe: unikanie opodatkowania, treść ekonomiczna, klauzula przeciwko unikaniu opodatkowania

1. UWAGI WSTĘPNE

Badanie treści ekonomicznej (ang. substance) działań podatników wpisuje się w kontekst inicjatyw podejmowanych w celu przeciwdziałania negatywnemu zjawisku unikania opodatkowania. Na konieczność analizowania tego aspektu zachowań podatników wskazuje się w dorobku nauki i rozstrzygnięciach sądowych, w szczególności w postaci formułowanych tzw. doktryn orzeczniczych. Element treści ekonomicznej przejawia się

\footnotetext{
* Dr, radca prawny i doradca podatkowy, manager w KPMG Tax M.Michna sp.k.
} 
także w formie konkretnych zapisów prawnych, np. w postaci kodyfikacji doktryn orzeczniczych bazujących na koncepcji substance, czy też w kontekście klauzul ogólnych przeciwko unikaniu opodatkowania.

Przedmiotem niniejszego artykułu jest przedstawienie podejścia do zagadnienia treści ekonomicznej, prezentowanego w Wielkiej Brytanii.

\section{BRYTYJSKIE DOKTRYNY ORZECZNICZE ODNOSZĄCE SIĘ}

DO KONCEPCJI SUBSTANCE

W Wielkiej Brytanii brak wyraźnych regulacji prawnych, kodyfikujących doktrynę economic substance w sposób samodzielny i kompleksowy ${ }^{1}$. Przez długi czas w brytyjskim orzecznictwie przeważała zresztą wprost przeciwna doktryna - form over substance - preferująca stosowanie literalnej wykładni prawa w sprawach podatkowych. Kluczowe założenia tej doktryny zostały sformułowane w słynnym wyroku z 1935 r. (a więc współczesnym do amerykańskiego rozstrzygnięcia Gregory v. Helvering ${ }^{2}$ ) w sprawie Duke of Westmister v. IRC. Orzeczenie dotyczyło próby minimalizacji obciążenia podatkowego polegającej na tym, że podatnik w miejsce wypłacanych służbie wynagrodzeń wprowadził rodzaj renty.

Renta ta odpowiadała swoją wysokością dotychczasowym wynagrodzeniom, jednakże - w przeciwieństwie do wynagrodzeń, niepotrącalnych z osobistego dochodu podatnika - była odliczalna od dochodu podlegającego opodatkowaniu ${ }^{3}$. W zaistniałym stanie faktycznym Izba Lordów wydała rozstrzygnięcie na korzyść podatnika. Zgodnie z wyrażonym w tym wyroku poglądem Lorda Tomlina,

każdy człowiek, jeśli tylko ma możliwość, jest uprawniony do prowadzenia swoich spraw w taki sposób, aby podatek należny na podstawie właściwego aktu prawnego był niższy niż byłby w innym przypadku. Jeśli to zamierzenie podatnika się powiedzie, wówczas - niezależnie od tego, jak negatywnie jego pomysłowość byłaby oceniana przez władze podatkowe lub innych podatników - nie może zostać zmuszony do zapłaty wyższego podatku4.

${ }^{1}$ Por. J. Hawkes, Substance in International Taxation. United Kingdom, „International Transfer Pricing Journal” 2014, wrzesień/październik, s. 368.

${ }^{2}$ Jedno z najgłośniejszych orzeczeń amerykańskiego sądownictwa w sprawach podatkowych, stanowiące podwaliny amerykańskiej doktryny orzeczniczej economic substance.

${ }^{3}$ Por. B. Brzeziński, Anglosaskie doktryny orzecznicze dotyczace unikania opodatkowania, Toruń 1996, s. 50.

${ }^{4}$ Por. M. Seiler, GAARs and Judicial Anti-Avoidance in Germany, the UK and the EU, Wien 2016, s. 42. 
Naturalną konsekwencją stosowanego przez brytyjskie sądy liberalnego (korzystnego dla podatników) podejścia było nasilające się i zagrażające finansom publicznym zjawisko unikania opodatkowania. $Z$ tej perspektywy za przełomowe dla angielskiej doktryny w sprawach podatkowych należy uznać wyroki z 1981 r. w sprawie Ramsay Ltd v. IRC oraz z 1984 r. w sprawie Furniss v. Dawson. Pierwszy ze wspomnianych wyroków dotyczył próby uniknięcia podatku od dochodu ze sprzedaży składników majątku (gospodarstwo rolne) poprzez wygenerowanie potrącalnych z tym dochodem strat kapitałowych. Zgodnie z zamysłem podatnika, powyższe miało nastąpić poprzez udzielenie przez spółkę Ramsay pożyczek specjalnie powołanej w tym celu spółce zależnej, odpowiednią modyfikację umów pożyczkowych, a następnie sprzedaż jednej z wierzytelności pożyczkowych, dzięki czemu wygenerowana została strata na sprzedaży akcji spółki zależnej. W zaistniałym stanie faktycznym spółka Ramsay stała na stanowisku, że sprzedaż wierzytelności z tytułu pożyczki nie przyniosła zysku kwalifikującego się do opodatkowania podatkiem od zysków kapitałowych, natomiast strata poniesiona w związku ze sprzedażą akcji spółki zależnej podlegała potrąceniu $\mathrm{z}$ dochodu osiągniętego na sprzedaży innych składników majątku spółki. Rozstrzygając sprawę, Izba Lordów - chociaż nie powoływała się na ustanowienie jakiejkolwiek nowej zasady orzeczniczej - uznała jednak, że transakcje zawierane wyłącznie w celu uniknięcia opodatkowania i pozbawione innych ekonomicznych bądź gospodarczych celów nie mogą wywierać skutków na płaszczyźnie prawa podatkowego ${ }^{5}$.

Patrząc wstecz, w literaturze wskazuje się, że znaczenie przypisywane orzeczeniu w sprawie Ramsay podlegało pewnej ewolucji i przeszło dwa stadia rozwoju. Początkowo uważano, że orzeczenie to wprowadziło do brytyjskiego prawa podatkowego zasadę nieważności (principle of fiscal nullity), koncepcję transakcji złożonych (composite transaction approach), doktrynę economic substance czy doktrynę step transaction. Sporadycznie sprawa Ramsay bywała nawet traktowana jako wprowadzająca orzeczniczą klauzulę ogólną przeciwko unikaniu opodatkowania. Wraz z upływem czasu okazało się jednak, że tzw. zasada/podejście Ramsay (Ramsay principle) approach) stanowi jedynie formę interpretacji ustawy ${ }^{6}$.

${ }^{5}$ Por. B. Brzeziński, Anglosaskie doktryny orzecznicze..., s. 54-55.

${ }^{6}$ Por. M. Seiler, GAARs and Judicial Anti-Avoidance..., s. 47. Także J. Freedman, Interpreting Tax Statutes: Tax Avoidance and the Intention of Parliament, „Law Quarterly Review" 2007, vol. 123 (January), s. 53. 
Wyrok w sprawie Furniss v. Dawson dotyczył z kolei próby uniknięcia podatku od zysków kapitałowych na sprzedaży udziałów. Działania podjęte przez podatnika polegały - w pierwszym etapie - na utworzeniu spółki zależnej w korzystnej rezydencji podatkowej (wyspa Man), do której zostały wniesione przeznaczone do sprzedaży udziały. Następnie - w drugim etapie - dokonana została sprzedaż udziałów z poziomu spółki zależnej. Pierwsza operacja stanowiła neutralną podatkowo zamianę udziałów. Natomiast operacja druga nie była opodatkowana $z$ tego powodu, że nie przyniosła zysku spółce zależnej. W zaistniałym stanie faktycznym, rozstrzygając jednak na korzyść administracji podatkowej, Izba Lordów sformułowała konkretne stanowisko wobec działań podatników - nazwane później Nową Doktryną (A New Approach) - pozwalające na dyskwalifikowanie na gruncie prawa podatkowego określonych schematów działań prowadzących do unikania opodatkowania ${ }^{7}$. Mianowicie, zgodnie z wyrażonym w tym wyroku stanowiskiem Lorda Brightmana,

po pierwsze, istnieć musi zaaranżowana [...] seria transakcji bądź - jak kto woli - transakcja złożona. Po drugie, musi tu występować też taka operacja, która nie ma innego celu gospodarczego oprócz uniknięcia opodatkowania. Jeżeli zachodzą jednocześnie obie te okoliczności, to operacja, o której wyżej mowa, nie powinna być brana pod uwagę przy opodatkowaniu. Sąd musi wówczas patrzeć na rezultat końcowy wszystkich zrealizowanych transakcji ${ }^{8}$.

Niepewność podatników co do praktycznego znaczenia New Approach, powstała po wyrokach w sprawie Ramsay oraz Furniss v. Dawson, została w pewnym stopniu ograniczona wyrokiem z 1989 r. w sprawie Craven v. White. Różnica w stanie faktycznym pomiędzy tym wyrokiem, a orzeczeniem w sprawie Furniss v. Dawson polegała na tym, że w orzeczeniu w sprawie Craven v. White wystąpił odstęp czasowy pomiędzy przeniesieniem udziałów do spółki zależnej a ich późniejszą sprzedażą ${ }^{9}$. Biorąc pod uwagę powyższy aspekt czasowy, sprawa została rozstrzygnięta na ko-

\footnotetext{
${ }^{7}$ Por. B. Brzeziński, Anglosaskie doktryny orzecznicze..., s. 56-57.

${ }^{8}$ Por. B. Brzeziński, Anglosaskie doktryny orzecznicze..., s. 57. Także M. Seiler, GAARs and Judicial Anti-Avoidance..., s. 55.

${ }^{9}$ Por. M. Seiler, GAARs and Judicial Anti-Avoidance..., s. 57. Jak stwierdził Lord Oliver, zważywszy, że transakcja nie została „z góry zaplanowana ani złożona w tym znaczeniu, że w momencie przeniesienia udziałów do spółki pośredniczącej można było z góry przewidzieć, gdzie udziały zostaną ostatecznie przeniesione, stan faktyczny sprawy nie spełniał kryteriów wyrażonych (w sprawie Furniss v. Dawson) przez Lorda Brightmana”. Por. ibidem, s. 58.
} 
rzyść podatnika, a jednocześnie sformułowane zostały pewne ograniczenia odnośnie praktycznego zastosowania zasady Ramsay. Mianowicie - jak stwierdził Lord Oliver - w celu pominięcia transakcji musi zostać stwierdzone, że

(1) w momencie, w którym była realizowana transakcja pośrednia, szereg transakcji został z góry zaplanowany w sposób pozwalający na osiągnięcie określonego rezultatu, (2) transakcja nie miała żadnego innego celu poza ograniczeniem zobowiązania podatkowego, (3) w czasie realizacji transakcji nie było prawdopodobne, aby zaplanowane zdarzenia nie zostały zrealizowane w założony sposób, w związku z czym transakcja pośrednia w ogóle nie była analizowana jako mogąca mieć niezależny byt, oraz (4) z góry założone zdarzenia faktycznie miały miejsce ${ }^{10}$.

W analizowanym orzeczeniu potwierdzono zatem, że obawy po orzeczeniach w sprawie Ramsay oraz Furniss v. Dawson - wyrażane wcześniej przez środowiska biznesowe - były bezpodstawne, bowiem zasada Ramsay została zastosowana $\mathrm{z}$ zachowaniem ograniczen ${ }^{11}$.

Powrót w orzecznictwie brytyjskim do literalnej wykładni prawa w sprawach podatkowych można obserwować w wyrokach: z 2001 r. w sprawie MacNiven v. Westmoreland Investments Ltd oraz z 2004 r. w sprawie Barclays Mercantile Business Finance Ltd v. Mawson. Pierwszy ze wspomnianych wyroków dotyczył możliwości skorzystania z odliczenia podatkowego z tytułu zapłaconych odsetek. Mianowicie w wyniku nieudanych inwestycji podatnik - spółka Westmoreland Investment Limited - posiadała zobowiązanie wobec swojego ostatecznego właściciela (spółki powiązanej) sięgające 70 milionów funtów, z czego ponad 40 milionów stanowiły naliczone lecz niezapłacone odsetki. Zgodnie z obowiązującymi w tamtym czasie przepisami podatkowymi odsetki podlegały zaliczeniu do kosztów na zasadzie kasowej, tj. dopiero w momencie, w którym zostały faktycznie zapłacone. Mając na uwadze powyższe, wdrożony schemat miał na celu umożliwienie spółce właścicielskiej chociaż częściowe zrekompensowanie chybionej inwestycji i zmierzał do tego, by przynajmniej część naliczonych odsetek mogła zostać uznana za zapłacone. Zapłacone odsetki stanowiłyby wówczas koszty do odliczenia od ewentualnych przyszłych dochodów, co czyniłoby spółkę atrakcyjną dla potencjalnych nabywców. W celu uzyskania tego efektu Westmoreland Investment Ltd pożyczyła od swojego dotychczasowego wierzyciela dalszych 20 milionów funtów, które zostały

\footnotetext{
${ }^{10}$ Por. ibidem.

${ }^{11}$ Ibidem.
} 
wykorzystane na spłatę części naliczonych odsetek. Przepływ kapitału był wyłącznie okrężny, a naliczone odsetki zostały de facto zastąpione dalszym finansowaniem. Administracja skarbowa odmówiła uznania takich odsetek za „zapłacone” dla celów podatkowych, jednakże sprawa została ostatecznie rozstrzygnięta na korzyść podatnika. Zgodnie ze stanowiskiem Izby Lordów, 20 milionów funtów odsetek należało uznać za „zapłacone” w rozumieniu ustawy podatkowej pomimo tego, że fundusze użyte na spłatę odsetek zostały pożyczone od wierzyciela bez jakiegokolwiek celu gospodarczego innego niż uzyskanie korzyści podatkowej ${ }^{12}$.

Z kolei w wyroku w sprawie Barclays Mercantile Business Finance Ltd v. Mawson rozstrzygana była kwestia, czy wydatek spółki (BMBF - spółka finansowa należąca do grupy Barclays) na zakup rurociągu został poniesiony w taki sposób, by umożliwić tej spółce skorzystanie z ulgi inwestycyjnej dla celów podatkowych. Stan faktyczny przedstawiał się $\mathrm{w}$ ten sposób, że spółka BMBF dokonała zakupu rurociągu od innego podmiotu, by następnie udostępnić go do korzystania temu podmiotowi w ramach leasingu zwrotnego. Zgodnie ze szczegółami transakcji, sprzedawca rurociągu (a następnie jego leasingobiorca) nie mógł w sposób swobodny dysponować uzyskaną ceną sprzedaży, bowiem została ona zdeponowana jako zabezpieczenie płatności leasingowych w spółce powiązanej z Barclays. Jednakże sama transakcja sprzedaży miała charakter rzeczywisty i została dokonana pomiędzy podmiotami niepowiązanymi. Rozstrzygając sprawę na korzyść spółki BMBF Izba Lordów - reprezentowana przez Lorda Nichollsa - uznała za zbyt daleko idącą konkluzję, że transakcja lub elementy transakcji nie posiadające celu gospodarczego zawsze powinny być pomijane dla celów podatkowych. Mianowicie zwrócono uwagę, że obowiązujące przepisy dotyczące możliwości skorzystania $z$ ulgi inwestycyjnej dotyczą tylko zachowania leasingodawcy. Przepisy nie odnoszą się natomiast do tego, w jaki sposób leasingobiorca może dysponować ceną sprzedaży, ani też do tego, $\mathrm{z}$ jakich środków ma zapłacić raty leasingowe. Jedynym, co miało znaczenie, był wydatek na zakup rurociągu poniesiony przez $\mathrm{BMBF}^{13}$.

${ }^{12}$ Por. A. Roycroft, A Welcome Decision - Andrew Roycroft comments on the House of Lords decision in MacNiven v. Westmoreland Investments Limited, „Taxation” 2001, https://www.taxation.co.uk/articles/2001/03/15/902/welcome-decision-andrew-roycroftcomments-house-lords-decision-macniven-v-we.

${ }^{13}$ Por. J. Freedman, Interpreting Tax Statutes..., s. 64-65. 
Podsumowując ten stan rzeczy w orzecznictwie brytyjskim, jak stwierdził Lord Hoffman, jedynym sposobem, w który Parlament może wyrazić wolę nałożenia podatku są przepisy prawa, z których wynika opodatkowanie. W takiej sytuacji sądom może być powierzone jedynie wykonanie woli Parlamentu. Przyjęcie jakiegokolwiek innego podejścia prowadziłoby na niebezpieczny i nieprzewidywalny grunt ${ }^{14}$. Szeroko podzielane stanowisko w tym zakresie zostało także wyrażone w Zielonym Budżecie Instytutu Studiów Fiskalnych (Institute for Fiscal Studies Green Budget) w 2006 r. Jak zostało tam stwierdzone,

nie może być mowy o unikaniu opodatkowania w sytuacji, gdy - zdaniem sędziów - Parlament chybił i określone postępowanie jest zgodne z literą prawa, niezależnie od tego, jak bardzo oczywiste może się wydawać, że intencją Parlamentu nie było objęcie przepisami takiego właśnie postępowania podatnika. Zgodnie z prawem, skoro coś zostało przewidziane przez Parlament, to podatnik nie unika opodatkowania, ograniczając wysokość swojego zobowiązania podatkowego do tego, co zostało przewidziane $^{15}$.

Mając na uwadze manifestowaną w orzecznictwie niechęć sędziów do orzekania na podstawie treści ekonomicznej, jeśli miałoby to nastąpić $\mathrm{z}$ pominięciem litery prawa, rozwiązaniem sugerowanym w literaturze było wprowadzenie do brytyjskiego systemu podatkowego uwzględniającej koncepcję substance klauzuli ogólnej przeciwko unikaniu opodatkowania (General Anti-Avoidance Rule, w skrócie GAAR). Jak bowiem wskazywano, jeśli koncepcja econimic substance miałaby mieć pierwszeństwo nad pojęciami prawnymi, powinno to być jednoznacznie zrozumiałe i uwzględnione w procesie legislacyjnym. W szczególności argumentowano, że nawet przy dużej ilości szczegółowych przepisów pozostają luki w systemie, których sądy nie są w stanie „załatać”, odwołując się - na wyższym poziomie ogólności - do treści ekonomicznej, bowiem nie ma żadnych wskazówek, które by je do tego uprawniały. Wręcz przeciwnie, mogłoby się to nawet wydawać niewłaściwe, zważywszy, że taka możliwość nie została uwzględniona przez legislatora ${ }^{16}$. Jak stwierdził Lord Hoffmann, jedną rzeczą jest bowiem celowościowa wykładnia przepisów, a inną korygowanie bardzo nakazowych norm prawnych poprzez włączenie postanowień, które mogły być

\footnotetext{
${ }^{14}$ Por. L. Hoffmann, Tax Avoidance, „British Tax Review” 2005, nr 2, s. 206.

${ }^{15}$ Por. The IFS Green Budget: January 2006, s. 174, https://www.ifs.org.uk/publications/3552.

${ }^{16}$ Por. J. Freedman, Interpreting Tax Statutes..., s. 74.
} 
- lecz nie zostały - wprowadzone ${ }^{17}$. Realizacja przez GAAR zakładanego w literaturze celu wymagałaby jednak spełnienia określonych warunków, m.in. tego, by klauzula zawierała zasady wykraczające poza reguły zwykłej legislacji. W konsekwencji odniesienie - przykładowo - do nadużycia (abuse) mogłoby się okazać niewystarczające. Klauzula powinna bowiem odwoływać się do zasad, które mogą być stosowane do oceny transakcji w sposób obiektywny; lista takich zasad powinna zawierać kryterium treści ekonomicznej, choć nie ograniczać się do niego ${ }^{18}$.

\section{KONCEPCJA SUBSTANCE A BRYTYJSKA KLAUZULA OGÓLNA}

PRZECIWKO UNIKANIU OPODATKOWANIA

Odwrót od doktryn orzeczniczych skierowanych przeciwko unikaniu opodatkowania doprowadził do zwiększenia wysiłków administracji skarbowej, podejmowanych w celu wprowadzenia GAAR ${ }^{19}$. Jak stwierdza się w literaturze, ostatecznym powodem intensyfikacji prac nad klauzulą stał się wyrok z 2011 r. w sprawie Mayes v. HMRC ${ }^{20}$. Orzeczenie dotyczyło próby wykreowania straty podatkowej, w znaczący sposób przewyższającej wysokość straty ekonomicznej, przy wykorzystaniu schematu optymalizacyjnego opartego o polisy z tytułu ubezpieczenia na życie. Schemat (funkcjonujący pod nazwą SHIPS 2) był realizowany w siedmiu z góry określonych i całkowicie bezcelowych - z gospodarczego punktu widzenia - krokach (nawet podatnik sam przyznał, że transakcja została zrealizowana w celu uniknięcia opodatkowania). Sprawa została jednak rozstrzygnięta na niekorzyść administracji skarbowej. Wydając wyrok w niższej instancji, sędzia Proudman wyraził nawet „zrozumienie dla instynktownej reakcji, że tak oczywisty schemat nie powinien być skuteczny”. Stwierdzono jednak, że

${ }^{17}$ Por. L. Hoffmann, Tax Avoidance, s. 205.

${ }^{18}$ Por. J. Freedman, Interpreting Tax Statutes..., s. 87.

${ }^{19}$ Jak stwierdza się w literaturze, żaden ustawodawca nie może pozwolić na to, aby podatnicy kontynuowali prowadzenie swoich spraw w taki sposób, jakby system podatkowy był dobrowolny (zapłać administracji skarbowej lub zapłać doradcy), ani na to, aby dochody państwa nie wystarczały na pokrycie potrzeb. Por. G. Loutzenhiser, Tiley's Revenue Law 2016, s. 102.

${ }^{20}$ Por. M. Seiler, GAARs and Judicial Anti-Avoidance..., s. 71. Jak zwraca uwagę ten autor, sprawa nie była nawet rozstrzygana przez Sąd Najwyższy, a jedynie przez Sąd Apelacyjny (Sąd Najwyższy odmówił przyjęcia tej sprawy do rozpoznania - por. https:// uk.practicallaw.thomsonreuters.com/4-511-7168?transitionType=Default\&contextData= (sc.Default)\&firstPage $=$ true \&comp $=$ pluk\&bhcp $=1$ ). 
opodatkowanie nie powinno opierać się na instynkcie, lecz na przepisach ustawy. Bez znaczenia z tej perspektywy pozostawał powód przystąpienia przez podatnika do danej transakcji ${ }^{21}$.

Kwestia zasadności wprowadzenia GAAR do brytyjskiego systemu podatkowego była analizowana przez tzw. Komisję Aaronsona (Aaronson Committee). Efektem jej prac stał się Raport (tzw. Aaronson Report ${ }^{22}$ ) z 11 listopada 2011 r., optujący za klauzulą o dość ograniczonym zakresie ${ }^{23}$. Mianowicie GAAR w kształcie rekomendowanym w raporcie miał mieć zastosowanie wyłącznie do transakcji o charakterze ewidentnych nadużyć. Celem miało być wprowadzenie umiarkowanej regulacji nie mającej zastosowania do rozsądnego planowania podatkowego, ale wymierzonej przeciwko porozumieniom mającym właśnie charakter nadużycia (abusive arrangements). W szczególności Raport wskazał na dwa wyznaczniki akceptowalnej klauzuli: pierwszy - aby miała ona zastosowanie wyłącznie do porozumień o charakterze anormalnym i drugi - aby miała ona zastosowanie wyłącznie w sytuacji, gdy porozumienie nie może być potraktowane jako uzasadnione korzystanie z rozwiązań przewidzianych przez ustawodawcę ${ }^{24}$. Jak wynika z Raportu, element treści ekonomicznej został uwzględniony w projekcie klauzuli nie wprost, ale pośrednio - w ramach przesłanek świadczących o tym, że dana transakcja ma charakter anormalny ${ }^{25}$.

Przepisy wprowadzające do brytyjskiego porządku prawnego klauzulę ogólną przeciwko unikaniu opodatkowania - właściwie zaś przeciwko nadużyciu ${ }^{26}$ prawa podatkowego - zostały ostatecznie uchwalone w ramach Fi-

${ }^{21}$ Por. M. Seiler, GAARs and Judicial Anti-Avoidance..., s. 71-72.

${ }^{22}$ GAAR Study. A study to consider whether a general anti-avoidance rule should be introduced into the UK tax system, http://webarchive.nationalarchives.gov.uk/20130102175714/ http://www.hm-treasury.gov.uk/d/gaar_final_report_111111.pdf, dalej: Raport.

${ }^{23}$ Por. E. Jensen, The Tiley Trilogy and U.S. Anti-avoidance Law, „eJournal of Tax Research” 2014, t. 12, nr 1, s. 83. Jak wskazuje ten autor, Komitet nie rekomendował wprowadzenia rozwiązań na kształt amerykańskich doktryn substance over form. W każdym wypadku Komitet rekomendował wprowadzenie rozwiązań prawnych, a nie poleganie na działaniach sądów (podjęcie działań legislacyjnych zostało przedstawione w Raporcie jako zgodne z zasadą praworządności).

${ }^{24}$ Por. Raport, s. 40.

${ }^{25}$ Por. Raport, s. 47. W Raporcie została wskazana lista cech wskazujących na anormalność transakcji, wśród których wymieniono sytuację, gdy rezultat danego działania podatnika, który miałby być uwzględniony dla celów podatkowych, jest znacząco niższy niż rzeczywisty ekonomiczny przychód, dochód lub zysk.

${ }^{26}$ A. Olesińska zwraca uwagę, że brytyjskie przepisy zostały zatytułowane jako „General Anti-Abusive Rule”, a nie - jak to zazwyczaj ma miejsce - jako „Anti-Avoidance 
nance Act 2013 (a następnie zmodyfikowane w ramach Finance Act 2016) 27 $^{27}$ i mają zastosowanie do transakcji, które zostały zrealizowane po 17 lipca 2013 r. $^{28}$ Klauzula obejmuje czynności (określone mianem uzgodnień podatkowych, tax arrangements), w odniesieniu do których można rozsądnie stwierdzić, że ich głównym celem (lub jednym z głównych celów) było osiągnięcie korzyści podatkowej. Ocena transakcji jest zatem dokonywana na podstawie kryteriów obiektywnych. Tax arrangements są jednak objęte klauzulą pod warunkiem, że mają charakter nadużycia ${ }^{29}$. Można o tym mówić, jeśli tax arrangements są uzgodnieniami takiego rodzaju, że - biorąc pod uwagę wszystkie okoliczności, w tym wskazane bezpośrednio w ustawie - przystąpienie do nich albo ich zrealizowanie nie może być rozsądnie oceniane jako rozsądny sposób działania (cannot reasonably be regarded as a reasonable course of action) w kontekście właściwych przepisów podatkowych ${ }^{30}$.

Ustawa wskazuje przy tym na przykładowe czynniki mogące wskazywać, że tax arrangements należy uznać za abusive; chodzi mianowicie o sytuacje, gdy:

- uzgodnienia podatkowe skutkują tym, że kwota przychodu, dochodu lub zysku dla celów podatkowych jest znacząco niższa niż kwota dla celów ekonomicznych,

- uzgodnienia podatkowe prowadzą do odliczeń lub strat, których wysokość dla celów podatkowych jest znacząco wyższa niż dla celów ekonomicznych,

Rule”, co stanowi odzwierciedlenie zamiaru wprowadzenia do brytyjskiego systemu podatkowego klauzuli w wersji stosunkowo „łagodnej” (są to przepisy skierowane przeciwko „nadużyciu”). Por. A. Olesińska, Klauzula ogólna przeciwko unikaniu opodatkowania, Toruń 2013, s. 237.

${ }^{27}$ Por. HM Revenue and Customs, General Anti-Abuse Rule (GAAR) guidance (Approved by the GAAR Advisory Panel effect from 31 March 2017), s. 4, https://www.gov.uk/ government/uploads/system/uploads/attachment_data/file/611577/gaar-parts-a-c-2017. pdf. Klauzula została uregulowana w części (part) 5 Finance Act 2013 oraz w załącznikach (schedules) 43-43C do tej ustawy.

${ }^{28}$ Por. ibidem, s. 10.

${ }^{29}$ Por. ibidem, s. 19.

${ }^{30}$ Por. punkt (section) 207(2) Finance Act 2013. Jak pisze A. Olesińska, „do powszechnego obiegu weszło sformułowanie, iż w normie zastosowano podwójny test zdrowego rozsądku - »double reasonableness test «”. Por. A. Olesińska, Klauzula ogólna przeciwko unikaniu..., s. 239. 
- uzgodnienia podatkowe są podstawą dla żądania zwrotu lub odliczenia podatku (w tym zagranicznego), który nie został i z dużym prawdopodobieństwem nie zostanie zapłacony ${ }^{31}$.

Mając na uwadze powyższe, można zatem stwierdzić, że o tym, czy dany tax arrangement nosi charakter nadużycia, świadczy porównanie treści ekonomicznej transakcji z tym, co podatnik stara się uzyskać dla celów podatkowych.

\section{Podsumowanie}

Zasadniczo doktryny orzecznicze oparte na koncepcji substance nie znalazły w Wielkiej Brytanii szerszego zastosowania. Z jednej bowiem strony na gruncie brytyjskim nie przyjęły się doktryny funkcjonujące np. w Stanach Zjednoczonych (economic substance, business purpose, substance over form i inne). Wręcz przeciwnie - możliwość inkorporowania tych doktryn do brytyjskiego porządku prawnego została w piśmiennictwie poddana zdecydowanej krytyce ${ }^{32}$. Z drugiej natomiast strony doktryny wypracowane przez rodzime orzecznictwo (zasada Ramsay, New Approach) ostatecznie stały się jedynie sposobem interpretacji ustawy, nie dając możliwości rozstrzygania na podstawie treści ekonomicznej, a z pominięciem litery prawa. Przy jednoczesnych stałych wysiłkach w celu minimalizacji obciążeń podatkowych, podejmowanych przez podatników, naturalną konsekwencją takiego stanu rzeczy stało się ostatecznie wprowadzenie do brytyjskiego porządku prawnego klauzuli ogólnej przeciwko unikaniu opodatkowania (a właściwie przeciwko nadużyciu prawa podatkowego). Klauzula ta uwzględnia element treści ekonomicznej w sposób pośredni, poprzez definiowanie transakcji (tax arrangements) noszących charakter nadużycia.

${ }^{31}$ Por. punkt (section) 207(4) Finance Act 2013. Jak pisze A. Olesińska, do okoliczności, które mogą wskazywać na to, że czynność ma charakter nadużycia, należy m.in. to, że „W wyniku transakcji podatnik uzyskał dochód znacząco niższy niż ten, jakiego należałoby oczekiwać mając na względzie ekonomiczną racjonalność działania”. Por. A. Olesińska, Klauzula ogólna przeciwko unikaniu..., s. 239.

32 Por. E. Jensen, The Tiley Trilogy..., s. 75 i nast. Autor odnosi się tam do krytycznej analizy amerykańskich doktryn orzeczniczych, przedstawionej przez Johna Tileya w słynnej serii artykułów (tzw. trylogia Tileya) opublikowanych w latach 1987-1988 w „British Tax Review". 


\section{BIBLIOGRAFIA}

Brzeziński Bogumił, Anglosaskie doktryny orzecznicze dotyczące unikania opodatkowania, Toruń 1996.

Freedman Judith, Interpreting Tax Statutes: Tax Avoidance and the Intention of Parliament, „Law Quarterly Review” 2007, vol. 123 (Jan).

GAAR Study. A study to consider whether a general anti-avoidance rule should be introduced into the UK tax system.

Hawkes Jonathan, Substance in International Taxation. United Kingdom, „International Transfer Pricing Journal", wrzesień/ październik 2014.

HM Revenue and Customs, General Anti-Abuse Rule (GAAR) guidance (Approved by the GAAR Advisory Panel effect from 31 March 2017).

Hoffmann Leonard, Tax Avoidance, „British Tax Review” 2005, nr 2

Jensen Erik, The Tiley Trilogy and U.S. Anti-avoidance Law, „eJournal of Tax Research” 2014, t. $12, \mathrm{nr} 1$.

Loutzenhiser Glen, Tiley's Revenue Law 2016.

Olesińska Agnieszka, Klauzula ogólna przeciwko unikaniu opodatkowania, Toruń 2013.

Roycroft Andrew, A Welcome Decision - Andrew Roycroft comments on the House of Lords decision in MacNiven v. Westmoreland Investments Limited, Taxation 2001.

Seiler Markus, GAARs and Judicial Anti-Avoidance in Germany, the UK and the EU, Wien 2016.

The IFS Green Budget, January 2006.

Summary. One of the ways of countering tax avoidance is investigating and examining of taxpayers' activities from the perspective of their economic substance. This can be achieved through judicial doctrines comprising the element of economic substance as well as through specific legislation (ex. codified General Anti-Avoidance Rules). In United Kingdom the judicial doctrines basing on the concept of economic substance are not commonly applied. On one hand Britain did not integrate the well-developed American anti-avoidance doctrines (economic substance, business purpose, substance over form). On the other hand the doctrines developed by domestic jurisdiction (Ramsay principle, New Approach) finally do not entitle the courts to rule according to business substance and disregarding the letter of law. However the element of economic substance is indirectly considered in the British General Anti-Abuse Rule.

Keywords: tax avoidance, economic substance, general anti-avoidance clause 